\title{
The Lipolytic System in Adipose Tissue of Toronto-KK and C57BL/KsJ Diabetic Mice. Adenylate Cyclase, Phosphodiesterase and Protein Kinase Activities
}

\author{
Floyd P. Kupiecki and Lonnie D. Adams \\ Diabetes and Atherosclerosis Research, The Upjohn Company, Kalamazoo, MI, USA
}

Summary. Epinephrine-stimulated lipolysis in epididymal fat pads of T-KK mice is low, compared to C57BL/6J controls, at $10-12$ weeks and $8-9$ months of age. Lipolysis in isolated fat cells is similarly unresponsive to epinephrine in $9-12$ week old T-KK and $d b$ mice, but cyclic AMP phosphodiesterase activity is normal. Basal adenyl eyclase activity in ghosts prepared from isolated fat cells of T-KK mice is elevated but epinephrine-stimulated activity is low compared to controls. Total cyclase activity, elicited by $\mathrm{NaF}$, is higher in T-KK mice. Adenyl cyclase activity in particulate fractions prepared from fat pad homogenates of $d b$ mice is low compared to control mice when expressed as total activity per fat pad. Unstimulated and cyclic AMP-stimulated protein kinase activities in fat pad homogenates are normal in T-KK mice, but in $d b$ mice unstimulated activity is depressed while stimulated activity is elevated.

Key words: T-KK mouse, $d \vec{b}$ mouse, adipose tissue, isolated fat cells, lipolysis, cyclic AMP phosphodiesterase, adenylate cyclase, protein kinase.
Hyperphagia, hyperglycemia, hyperinsulinemia, obesity and intermittent glucosuria have been found in the Toronto-KK (T-KK) mouse $[1,2]$, a strain obtained by inbreeding offspring of a cross between $\mathrm{KK}$ and $\mathrm{C57BL} / 6 \mathrm{~J}$ strains of mice [1]. More recently insulin insensitivity, abnormal glucose tolerance and abnormal gluconeogenesis have been added to the list of disorders found in these mice and all abnormalities have become less severe in one year old mice [3]. Also, profound histologic changes have been observed in epididymal fat of the T-KK mouse [4]. In 3-month old mice, fat cells were greatly enlarged, while at the age of 9 months cellularity, inflammation, foreign body granuloma, necrosis and scar formation were evident concurrently with a diminished amount of adipocytes.

We have studied lipolysis in the T-KK mouse and have measured the activities of phosphodiesterase, adenylate cyclase and protein kinase to determine whether the reduced lipolytic activity could be explained by an abnormal response of one of the enzymes. Further, we have studied the same enzyme systems in the $\mathrm{C} 57 \mathrm{BL} / \mathrm{KsJ} d b$ mouse in an attempt to find whether the reduced lipolytic activity is due to the same or different defects in these two strains of diabetic mice.

\section{Materials and Methods}

\section{Animals and Diet}

Male T-KK and C57BL/6J mice were obtained from the Upjohn colony. Male C57BL/KsJ-db and C57BL/Ks.J mice were purchased from the Jackson Laboratory, Bar Harbor, Maine. All animals were maintained on Purina Breeder Chow and were sacrificed by decapitation for all studies.

\section{Lipolysis in Epididymal Adipose Tissue}

For lipolysis studies in adipose tissue, $50-70 \mathrm{mg}$ pieces were incubated in duplicate in Potter-Elvehjem homogenizer tubes in a metabolic shaker oscillating at $80-90$ cycles $/ \mathrm{min}$. Ineubations were conducted for $2 \mathrm{~h}$ at $37^{\circ} \mathrm{C}$ in an atmosphere of $95 \%$ air, $5 \% \mathrm{CO}_{2}$. The medium consisted of Krebs-Ringer bicarbonate containing $3 \%$ bovine serum albumin (Armour), $0.90 \mathrm{ml}$, epinephrine as indicated and $1.0 \mathrm{mg}$ glucose in a final volume of $1.0 \mathrm{ml}$. The adipose tissue was homogenized and FFA were extracted from $0.50 \mathrm{ml}$ aliquots by the procedure of Dole [5] and titrated by the method of $\mathrm{K}_{0}$ and Royer [6].

\section{Isolation of Fat Cells for Lipolysis and Phosphodieste- rase Measurements}

Isolated fat cells were prepared by a modification of the method of Lech and Calvert [7]. Epididymal adipose tissue of 2 T-KK or 6 control mice $(2 \mathrm{~g}$ or slightly less) was minced and incubated $50 \mathrm{~min}$ in $7.5 \mathrm{ml}$ Krebs-Ringer bicarbonate containing $28 \mathrm{mg}$ of crude collagenase (Nutritional Biochemical Corp.). The cells were washed twice by suspending them in $5.0 \mathrm{ml}$ Krebs-Ringer bicarbonate and centrifuging at $500 \times g$. Cells were dispersed in $3.0 \mathrm{ml}$ of KrebsRinger bicarbonate and aliquots were used for lipolysis and phosphodiesterase studies. An aliquot of the final cell suspension was digested for $30 \mathrm{~min}$ at $100^{\circ} \mathrm{C}$ in $1 \mathrm{~N} \mathrm{NaOH}$. A second portion was centrifuged and the suspending medium was digested as above. Both were assayed for protein by the method of Lowry [8]. Lipolytic activity of isolated fat cells was measured by incubating $0.20 \mathrm{ml}$ of cell suspension (diluted 1:1) in $0.30 \mathrm{ml}$ of Krebs-Ringer bicarbonate medium, pH. 7.2, containing $3 \%$ bovine serum albumin, $0.50 \mathrm{mg}$ glucose and epinephrine as indicated, in a final volume 
of $0.50 \mathrm{ml}$. Incubation of cells, extraction and titration of FFA was conducted as described for lipolysis in pieces of adipose tissue.

Phosphodiesterase activity in homogenates of isolated fat cells was measured by a modification of the methods of Brooker et al. [9] and of Loten and Sneyd [10]. The method is based on the fact that unreacted cyclic AMP is adsorbed by an ion-exchange resin and does not interfere with the detection of unbound labelled adenosine. The incubation mixture for the high $\mathrm{Km}$ phosphodiesterase consisted of $0.10 \mathrm{mM}$ cyclic AMP- ${ }^{3} \mathrm{H}(0.42 \mu \mathrm{Ci} / \mathrm{mI}), 3 \mathrm{mM}, \mathrm{MgSO}_{4}$ $40 \mathrm{mM}$, Tris-HCl, $\mathrm{pH} 7.5,50 \mu \mathrm{g}$ king cobra venom (Ophiophaqus hanna) and 0.06 or $0.12 \mathrm{ml}$ of fat cell homogenate $(40-180 \mu \mathrm{g}$ of protein) in a final volume of $0.40 \mathrm{ml}$. Incubation was carried out at $30^{\circ} \mathrm{C}$ for $15 \mathrm{~min}$. The reaction was stopped by cooling the mixture in ice, and ice water was added to a final volume of $1.50 \mathrm{ml}$. One-tenth of the diluted mixture thanol $(0.01 \mathrm{ml})$ in a final volume of $1.00 \mathrm{ml}$. Incubations were conducted as for high $\mathrm{Km}$ activity. The suspension of resin $(0.80 \mathrm{ml})$ was added to the chilled reaction mixture and the subsequent procedure was as described for the high $\mathrm{Km}$ phosphodiesterase activity.

\section{Preparation of Fat Cell Ghosts and Measurement of Adenyl Cyclase}

Fat cells were isolated from adipose tissue of T-KK and C57BL/6J mice and converted to ghosts by the method of Rodbell [11]. Epididymal fat pads from 3 T-KK or 4 control mice were combined to prepare a single batch of fat cell ghosts. Adenyl cyclase was measured as described by Pohl, Birnbaumer and Rodbell [12] from the rate of formation of cyclic AMP from ATPa ${ }^{32}$ P. The reaction mixture contained final concentrations $3.2 \mathrm{mV}$ Tris-ATP, $5 \mathrm{mM} \mathrm{MgCl}, 25 \mathrm{mM}$ Tris- $\mathrm{HCl}(\mathrm{pH} 7.4), 10 \mathrm{mM}$ theo-

Table 1. Lipolysis in adipose tissue of 10-12 week old and $8-9$ month old $T-K K$ and control mice

\begin{tabular}{|c|c|c|c|c|c|}
\hline \multirow{2}{*}{ Age } & \multirow{2}{*}{ Strain } & \multirow{2}{*}{$\begin{array}{l}\text { Zero-Time } \\
\text { FFA }\end{array}$} & \multicolumn{3}{|c|}{ Released FFA } \\
\hline & & & Basal & $0.10 \mu \mathrm{g} / \mathrm{ml}$ Epi. & $0.20 \mu \mathrm{g} / \mathrm{ml}$ Epi. \\
\hline & & $\mu \mathrm{eq} / \mathrm{g}^{\prime}$ & $\mu e q / g$ & $\mu e q / g$ & $\mu e q / g$ \\
\hline $10-12$ week & T.KK & $4.50^{\mathrm{a}}$ & $-2.48^{b}$ & $0.63^{a}$ & $3.68^{a}$ \\
\hline $8-9$ month & T-KK & $16.64^{\mathrm{a}}$ & $1.71^{\mathrm{b}}$ & 1.00 & $\begin{array}{l}10.0 \\
12.26^{\mathrm{a}}\end{array}$ \\
\hline & Control & $\begin{array}{l}10.0 \pm 0 \\
8.33\end{array}$ & $\begin{array}{l}1.11 \\
-2.23\end{array}$ & 3.26 & 22.63 \\
\hline
\end{tabular}

Each number is the mean of duplicate measurements in 5 animals. Standard deviation is $1.25,2.94,1.29$ and 1.78 for $10-12$ week old T-KK and control mice for zerotime, basal, $0.10 \mu \mathrm{g} / \mathrm{ml}$ epi. and $0.20 \mu \mathrm{g} / \mathrm{ml}$ epi. respectively. Standard deviation is $2.15,2.89,6.22$ and 5.06 for $8-9$ month old T-KK and control mice for zero-time, basal, $0.10 \mu \mathrm{g} / \mathrm{ml}$ epi. and $0.20 \mu \mathrm{g} / \mathrm{ml}$ epi. respectively.

$$
\begin{aligned}
& \mathrm{a}=p \text { vs control }<0.01 \\
& \mathrm{~b}=p \text { vs control }<0.05
\end{aligned}
$$

was added to $0.80 \mathrm{ml}$ of a $50 \%$ settled volume of BioRad AG-IX, 2-400 mesh, which was previously packed in a column, washed with $1 \mathrm{~N} \mathrm{NaOH}$, repeatedly with water, with $1 \mathrm{~N} \mathrm{HCl}$ and finally with water to neutrality. Ten $\mathrm{ml}$ of Bray's solution was added and radioactivity was counted in a Packard liquid scintillation spectrometer.

The low $\mathrm{Km}$ phosphodiesterase activity was measured in a final volume of $0.15 \mathrm{ml}$. The mixture consisted of $0.05 \mathrm{ml}$ of a substrate mixture, $0.05 \mathrm{ml}$ of an incomplete enzyme mixture and $0.05 \mathrm{ml}$ of fat cell homogenate diluted $1: 10$ or 1:20 $(2-10 \mu \mathrm{g}$ of protein). The substrate mixture consisted of: $0.3 \mathrm{M}$ Tris-HCl pH $8.0(0.40 \mathrm{ml}), 0.5 \mathrm{M}$ EGTA acid $(0.05 \mathrm{ml})$, $0.60 \mathrm{M} \mathrm{MgSO}{ }_{4}(0.20 \mathrm{ml}), 2.4 \mathrm{mM}$ AMP $(0.05 \mathrm{ml}), 0.016$ $\mathrm{mM}$ unlabelled eyclic AMP $(0.10 \mathrm{ml})$ and $0.36 \mu \mathrm{Ci}$ cyclic AMP. ${ }^{3} \mathrm{H}$ in a final volume of $1.00 \mathrm{ml}$. The incomplete enzyme mixture consisted of: cobra venom (1 $\mathrm{mg}$ in $0.20 \mathrm{ml}$ ), bovine serum ablumin $(2 \mathrm{mg}$ in $0.20 \mathrm{ml}$ ), $0.30 \mathrm{M}$ Tris- $\mathrm{HCl} \mathrm{pH} 8.0(0.20 \mathrm{ml})$ and $0.50 \mathrm{M}$ mercapto- phylline, $0.1 \%$ serum albumin and an ATP-regenerating system consisting of $20 \mathrm{mM}$ creatine phosphate and creatine kinase, $1 \mathrm{mg} / \mathrm{ml}$ (Sigma, 115 units $/ \mathrm{mg}$ ). Final concentrations were $10 \mathrm{\mu g} / \mathrm{ml}$ epinephrine and $10 \mathrm{mM}$ sodium fluoride. Reactions were initiated by the addition of $20-45 \mathrm{mg}$ of membrane protein. The total reaction volume of $0.05 \mathrm{ml}$ was incubated for 10 min and the reaction was stopped by the addition of $0.10 \mathrm{ml}$ of a solution containing $34 \mathrm{mM}$ sodium dodecyl sulfate, $40 \mathrm{mM}$ ATP, $0.15 \mu \mathrm{Ci}$ of cyclic AMP-3 (Schwartz Bioresearch) and sufficient cyclic AMP to give a final concentration of $12.5 \mathrm{mM}$. After boiling for $3.5 \mathrm{~min}$ the reaction mixtures were diluted with $0.4 \mathrm{ml}$ of water and the cyclic AMP was purified by passage through an AG50W-X8, 100-200 mesh column (Bio-Rad Laboratories), and a $\mathrm{BaSO}_{4}$ precipitation step [11]. The eluate from the $\mathrm{BaSO}_{4}$ step was suspended in $15 \mathrm{ml}$ of scintillation fluid and counted in a Packard scintillation counter. The cyclic AMP $-{ }^{3} \mathrm{H}$ was used to calculate the recovery of cyclic 
AMP_32P from the reaction mixtures. Cyclase activity was calculated as pmoles of cyclic AMP/10 min/mg protein, measured by the method of Lowry [8].

Adipose Tissue Homogenates for Adenyl Cyclase and Cyclic AMP-Dependent Protein Kinase

Epididymal fat pads from individual mice were homogenized at $0-5^{\circ} \mathrm{C}$ in 3 volumes $(\mathrm{w} / \mathrm{v})$ of $250 \mathrm{mM}$ sucrose in a Potter-Elvehjem all-glass homogenizer. The homogenate was centrifuged at $8000 \times g$ for $10 \mathrm{~min}$ at $4^{\circ} \mathrm{C}$ and the fat was carefully removed and discarded. The remaining homogenate was centrifuged at $25000 \times g$ for $15 \mathrm{~min}$ and the supernatant fraction was used for assay of protein kinase activity. The pellet was washed by resuspending it in the original volume of $250 \mathrm{mM}$ sucrose and centrifuging at 25000 $\times g$ for $15 \mathrm{~min}$. The pellet was resuspended in 0.6 volume (based on weight of adipose tissue) of $1 \mathrm{mM}$ $\mathrm{KHCO}_{3}$ and the suspension was forced through nylon mesh ( 63 threads $\mathrm{cm}$ ) from a wide-mouth $5 \mathrm{ml}$ pipette. The suspension was used for assay of adenylate cyclase as described for fat cell ghosts above. Protein kinase activity in the supernatant fraction of the homogenate was measured by a modification of the method described by Corbin, et al. [13]. The reaction mixture contained $0.25 \mathrm{mM}$ ATP- $\gamma_{-}{ }^{32} \mathrm{P}(1-2.5 \mu \mathrm{Ci} /$ tube $)$, $10 \mathrm{mM}$ potassium phosphate, $\mathrm{pH}$ 6.5, $5 \mathrm{mM}$ magnesium acetate, $3.75 \mathrm{mM}$ sodium glycerol phosphate, $0.375 \mathrm{mM}$ EDTA, $400 \mu \mathrm{g}$ calf thymus histone (Sigma, Type IIA), $1.25 \mathrm{mM}$ cyclic AMP and $80 \mu \mathrm{g}$ of protein in a volume of $200 \mu \mathrm{l}$. The reaction mixtures were kept in ice and, after the addition of ATP, a $25 \mu$ aliquot was pipetted on Whatman 31 ET filter paper and the remainder was incubated at $30^{\circ} \mathrm{C}$ for $4 \mathrm{~min}$. At the end of the incubation period a second $25 \mu \mathrm{l}$ aliquot was put on paper and the papers were developed in $5 \%$ TCA according to the procedure of $\mathrm{Li}$ and Felmly [14]. ${ }^{32} \mathrm{P}$ incorporated into protein was measured by counting the radioactivity directly on paper in $15 \mathrm{ml}$ of Bray's solution.

\section{Results and Discussion}

Epinephrine-stimulated lipolysis is lower in T-KK mice compared to controls in 10-12 week old as well as in 8-9 month old mice (Table 1). The older group responds better than the 10-12 week old group. Basal lipolysis is also lower in the younger group but increases to be higher than in controls in $8-9$ month old mice. The increase in basal lipolysis appears to be questionable since there was basal FFA release in the young controls but net re-esterification in the older control group. However, if the zero time concentration of FFA in adipose tissue is considered to be a reflection of lipolysis in vivo, then there is a significant increase in the older over the younger group. This is consistent with the reported normalization of other metabolic parameters [3] and with the decrease of fat in adipose tissue of older T-KK mice [4].
To eliminate the possible influence of other types of cells in adipose tissue, the effect of epinephrine on lipolysis in isolated fat cells was measured. Table 2 shows that lipolysis in isolated fat cells is raised to a higher level in control mice than in both kinds of diabetic mice.

Attention was next given to cyclic AMP phosphodiesterase, one of the enzymes that controls the tissue concentrazions of cyclic AMP. Data in Table 3 show

Table 2. Lipolysis in isolated fat cells of 9-12 week old $T-K K$ and $d b$ mice

\begin{tabular}{|c|c|c|c|}
\hline \multirow{2}{*}{ Strain } & \multirow{2}{*}{$\begin{array}{l}\text { Zero-Time } \\
\text { FFA }\end{array}$} & \multicolumn{2}{|c|}{ Released FFA } \\
\hline & & Basal & $1.0 \mu \mathrm{g} / \mathrm{ml} \mathrm{Epi}$ \\
\hline & $\begin{array}{l}\mu e q / \mathrm{mg} \\
\text { protein }\end{array}$ & $\begin{array}{l}\mu e q / \mathrm{mg} \\
\text { protein }\end{array}$ & $\begin{array}{l}\mu \mathrm{eq} / \mathrm{mg} \\
\text { protein }\end{array}$ \\
\hline $\begin{array}{l}\text { T-KK } \\
\text { Control }\end{array}$ & $\begin{array}{l}1.26 \\
1.11\end{array}$ & $\begin{array}{l}0.06^{\mathrm{a}} \\
0.43\end{array}$ & $\begin{array}{l}0.54^{\mathrm{b}} \\
6.07\end{array}$ \\
\hline$d b$ & 1.26 & 0.21 & $0.26^{b}$ \\
\hline Control & 1.44 & 0.26 & 1.01 \\
\hline
\end{tabular}

Each number is the mean of duplicate measurements in 6 experiments. Standard deviation is $0.26,0.26$ and 2.06 for T-KK and control mice for zero-time, basal and epinephrine-stimulated and $0.33,0.20$ and 0.30 for $d b$ and control mice for zero-time, basal and epinephrinestimulated respectively.

$$
\begin{aligned}
& \mathrm{a}=p \text { vs control }<0.05 \\
& \mathrm{~b}=p \text { vs control }<0.01
\end{aligned}
$$

Table 3. Low $K m$ and high $K m$ cyclic $A M P$ phosphodiesterase activities in isolated fat cells of T-KK and $d b$ mice

\begin{tabular}{lll}
\hline Phosphodiesterase & Strain & Cyclic AMP Hydrolyzed \\
\hline \multirow{2}{*}{ Low Km } & & $p$ moles/mg protein \\
& T-KK & 6464 \\
& Control & 6385 \\
& $d b$ & 4254 \\
& Control & 4843 \\
High Km & T-KK & n moles $/ \mathrm{mg}$ protein \\
& Control & 150 \\
& db & 85 \\
& Control & 90
\end{tabular}

Each number is the mean of duplicate measurements in 6 experiments. Standard deviation is 2889 for low $\mathrm{Km}$ T-KK and control and 1509 for $d b$ and control. For high Km it is 58 for T-KK and control, and 35 for $d b$ and control. All values for T-KK and $d b$ mice are not significantly different from controls.

that in T-KK and $d b$ mice, both low and high $\mathrm{Km}$ phosphodiesterase activities do not differ from those found in normal mice.

The response of adenyl cyclase in fat cell ghosts of $\mathrm{T}-\mathrm{KK}$ mice to the stimulating effect of epinephrine is low compared to that found in ghosts of the C57BL/ $6 J$ controls (Table 4). The percentage increase produced by NaF is the same for both groups, but the total amount of cyclase activity in ghosts of T-KK mice is greater since basal activity is significantly greater in T-KK mice. 
To compare adenyl cyclase activity in $d b$ and control mice, particulate fractions of fat pads were used in preference to ghosts prepared from isolated fat cells. This choice was made for the following reasons: a) Larger fat cells lysed during isolation leaving ghosts from the population of smaller or normal fat cells : b) to obtain the required amount of ghosts, it would have been necessary to pool adipose tissue of several animals, and c) protein kinase activity could be measured in the same homogenates used for assay of adenyl cyclase activity. Since adenyl cyclase activity in particulate fractions was stimulated to the

Table 4. Adenylate cyclase activity in fat cell ghosts of T-KK mice

\begin{tabular}{llll}
\hline \multirow{2}{*}{ Strain } & \multirow{2}{*}{ Basal activity } & \multicolumn{2}{c}{ Stimulated activity } \\
\cline { 3 - 4 } & & Epinephrine & $\mathrm{NaF}$ \\
\hline & $\left(p\right.$ moles $/ \mathrm{mg}^{2}$ protein $)$ & (-fold over basal) & \\
T-KK & $635 \pm 121^{\mathrm{a}}$ & $2.2^{\mathrm{b}}$ & 4.7 \\
Control & $355 \pm 67$ & 4.2 & 4.6 \\
\hline
\end{tabular}

Basal values represent mean \pm S.E.M. for 8 ghost preparations in each group prepared and assayed in triplicate as described in the text.

a $P$ vs. control $<0.05$

b $P$ vs. control $<0.01$

Table 5. Adenylate cyclase activity in homogenates of adipose tissue of $T-K K$ and $d b$ mice

\begin{tabular}{llll}
\hline Strain & Basal activity & \multicolumn{2}{c}{ Stimulated activity } \\
\cline { 2 - 4 } & (pmoles/mg protein) & (-fold over basal) \\
T-KK & $289 \pm 80$ & 1.6 & 3.0 \\
Control & $251 \pm 70$ & 1.6 & 2.6 \\
db & $146 \pm 33$ & 1.6 & 3.3 \\
Control & $190 \pm 40$ & 1.3 & 3.0 \\
\hline
\end{tabular}

Basal values represent mean \pm S.E.M. for 5 animals per group. All values for T-KK and $d b$ mice are not significantly different from controls.

same extent in $d b$ and control mice by both epinephrine and $\mathrm{NaF}$ (Table 5), identical experiments were done with T-KK mice. Unlike ghosts, particulate fractions of T-KK mice were stimulated to the same extent by epinephrine and $\mathrm{NaF}$ as particulate fractions of control mice (Table 5). However, the results show that basal and stimulated cyclase activities are reduced in homogenates of adipose tissue compared to fat cell ghosts. These data will be evaluated in another way after a consideration of protein kinase activity in the homogenates. The specific activities of both unstimulated and cyclic AMP-stimulated protein kinases are the same in T-KK and control mice (Table 6 ). In $d b$ mice unstimulated activity is low but cyclic AMP-stimulated activity is high as compared to controls. Total adenyl cyclase and protein kinase activities in fat pad homogenates of T.KK and $d b$ mice are compared in Table 7 . The total cyclase and cyclic AMP-stimulated protein kinase activities are the same in T-KK mice and controls. In $d b$ mice cyclase is low but kinase activity is high as compared to controls.

In summary, epinephrine-stimulated lipolysis is defective in T-KK and $d b$ mice, while cyclic AMP phosphodiesterase appears to be normal. The response of T-KK ghosts to epinephrine is abnormally low but total cyclase activity (response to $\mathrm{NaF}$ ) is elevated. A comparison of adenyl cyclase activity in adipose tissue homogenates of T-KK and $d b$ mice suggests that

Table 6. Specific activities of unstimulated and $c-A M P$. stimulated protein kinase in $T-K K$ and $C 57 B L / K s . J$ db mice and controls

\begin{tabular}{lll}
\hline Strain & \multicolumn{2}{l}{$\begin{array}{l}\text { pmoles }{ }^{32} \mathrm{P} \text { incorporated } / \mathrm{mg} \\
\text { protein }\end{array}$} \\
\cline { 2 - 3 } & Unstimulated & +c-AMP \\
\hline T-KK & $422 \pm 111$ & $1551 \pm 60$ \\
C57BL/6J Control & $542 \pm 120$ & $\mathbf{1 8 1 4 \pm 2 8 7}$ \\
C57BL/KsJ db & $271 \pm 51^{\mathrm{a}}$ & $2274 \pm 220^{\mathrm{b}}$ \\
C57BL/KsJ Control & $684 \pm 153$ & $1237 \pm \mathbf{1 5 9}$ \\
\hline
\end{tabular}

Each number represents mean \pm S.E.M. for 5 animals.

a $P$ vs. control $<0.002$

b $P$ vs. control $<0.005$

Table 7. Total adenylate cyclase and cyclic $A M P$-dependent protein kinase activity in fat pad homogenates

\begin{tabular}{lll}
\hline Strain & $\begin{array}{l}\text { Adenyl cyclase } \\
\text { p moles/fat pad }\end{array}$ & $\begin{array}{l}\text { Protein kinase } \\
\text { pmoles }\end{array}$ \\
incorporated/fat pad \\
\hline T-KK & $655 \pm 146$ & $13626 \pm 2309$ \\
Control & $411 \pm 68$ & $12303 \pm 2353$ \\
$d b$ & $348 \pm 65^{\mathrm{a}}$ & $12464 \pm \mathbf{1 6 8 5}$ \\
Control & $627 \pm 93$ & $\mathbf{5 2 9 6 \pm 7 1 5}$ \\
\hline
\end{tabular}

Values represent mean \pm S.E.M. for 5 animals per group.

a $P$ vs. control $<0.05$

b $P$ vs. control $=0.002$

cyclase is deficient in $d b$ mice. However, the cyclase deficiency is accompanied by an increase in the response of protein kinase to cyclic AMP. These results indicate that T-KK and $d b$ mice differ with respect to adenyl cyclase and protein kinase activities in their adipose tissue. However, this observation does not show whether these abnormalities account for the deficient lipolysis in these animals.

Acknowledgement. We thank Drs. John R. Schultz and Phillip I. Good for their skilful assistance in analysis of the data.

\section{References}

1. Dulin, W. E., Wyse, B.M. : Diabetes in the KK mouse. Diabetologia 6, 317-323 (1970)

2. Appel, M.C., Chang, A.Y., Dulin, W.E.: Metabolic abnormalities in livers and islets of Langerhans in a diabetic mouse. Physiologist 14, 103 (1971) 
3. Wyse, B.M., Dulin, W.E.: Further characterization of diabetes-like abnormalities in the T-KK mouse. Diabetologia 10, 617-623 (1974)

4. Soret, M. G., Kupiecki, F.P., Wyse, B.M. : Epididymal fat pad alterations in mice with spontaneous obesity and diabetes and with chemically induced obesity. Diabetologia 10, 639-648 (1974)

5. Dole, V.P.: A relation between non-esterified fatty acids in plasma and the metabolism of glucose. J. clin. Invest. 35, 150-154 (1956)

6. Ko, H., Royer, M.E.: A submicromolar assay for nonpolar acids in plasma and fat tissue. Anal. Biochem. 20, 205-214 (1967)

7. Lech, J.J., Calvert, D.N.: Protein content and osmotic behavior of isolated fat cells. J. Lipid Res. 7, $561-564(1966)$

8. Lowry, O.H., Rosebrough, N.J., Farr, A.L., Randall, R.J.: Protein measurement with the Folin phenol reagent. J. biol. Chem. 193, 265-275 (1951)

9. Brooker, G., Thomas, L.J., Jr., Appleman, M.M.: The assay of adenosine $3^{\prime}, 5^{\prime}$-cyclic monophosphate and guanosine $3^{\prime}, 5^{\prime}$-cyclic monophosphate in biological materials by enzymatic radioisotopic displacement. Biochemistry 7, 4177-4181 (1968)
10. Loten, E.G., Sneyd, J.G.T.: An effect of insulin on adipose-tissue adenosine $3^{\prime}, 5^{\prime}$-cyclic monophosphate phosphodiesterase. Biochem. J. 120, 187-193 (1970)

11. Rodbell, M.: Metabolism of isolated fat cells. V. Preparation of "ghosts" and their properties; adenyl cyclase and other enzymes. J. biol. Chem. 242, 5744$5750(1967)$

12. Pohl, S.L., Birnbaumer, L., Rodbell, M.: Glucagonsensitive adenyl cyclase in plasma membrane of hepatic parenchymal cells. Science 164, 566-567 (1969)

13. Corbin, J.D., Brostrom, C.O., Alexander, R.L., Krebs, E. G. : Adenosine 3',5'-monophosphate-dependent protein kinase from adipose tissue. J. biol. Chem. 247, 3736-3743 (1972)

14. Li, H.C., Felmly, D.A.: A rapid paper chromatographic assay for protein kinase. Anal. Biochem. 52, $300-304(1973)$

Dr. Floyd P. Kupiecki

Diabetes and Atherosclerosis Research

The Upjohn Co.

Kalamazoo, Mich. 49001

USA 